\title{
PERSILIEJIMO POTENCIALO FORMAVIMASIS IR SKLAIDA VERSLO ORGANIZACIJOSE
}

\author{
MARIJA KuČINSKIENE் ${ }^{1}$, DAINIUS BALIŪNAS ${ }^{2}$ \\ Vilniaus universitetas (Lietuva)
}

\begin{abstract}
ANOTACIJA
Straipsnyje analizuojama persiliejimo reiškinio kilmė organizacijose aplinkos pokyčiu kontekste ir tarporganizacinių veiksnių įtaka inovatyvių produktų (paslaugų ir prekių) kilmei. Straipsnyje didelis dėmesys skiriamas potencialių, turinčių persiliejimo potencialą veiksnių, tarpusavio ryšiams, naujų produktų kilmės poveikiui ekonominės plètros procesams. Nustatyta, kad žmogiškujų išteklių kuriami persiliejimo veiksniai sietini su inovatyvių organizacijų veiklos procesais, užduočių atlikimo laiku ir efektyviu technologijų diegimu.

PAGRINDINIAI ŽODŽIAI: verslo organizacija, persiliejimas, veiksniai, inovacija.
\end{abstract}

JEL KLASIFIKACIJA: O30, M 10

Ivadas

Šiuolaikinėmis sudètingos aplinkos sąlygomis ir vis labiau tobulëjant technologijoms, ryškèjant naujoms konkurencijos formoms, rinkoms tampant vis globalesnèms, kyla poreikis ịvertinti technologijų spartą ir jų procesų plètrą bei sklaidą - persiliejimą ị visas verslo organizacijų veiklos sritis. Atsižvelgiant ị globalizacijos iššūkius ekonominei, politinei, socialinei-kultūrinei, technologinei, aplinkosauginei aplinkoms, persiliejimo veiksnių veiksmingumo inovatyviems sprendimams verslo organizacijose atsirasti įvertinimas tampa ypač svarbus ir verčia skirti ypatingą dèmesị kuriamų produktų kokybei bendraja prasme gerinti.

Verslas, siekdamas pagrindinio tikslo - pelningumo didinimo, neatsižvelgia ị veiksnius ir jų pasekmes, kurios gali sukelti BVP nuosmuki ar net lemti valstybės ekonominio žlugimo (bankroto) riziką. Prognozuojant tokių veiksnių kilmę ir pasekmes gyvybiškai svarbu suprasti ir ištirti jų (veiksnių) veikimo bei atoveiksmio principus ir pasekmes. Identifikuojant svarbius veiksnius, kurie veikia ekonominius procesus, svarbu suprasti jų tarpusavio sąsajas ir sąveikos svarbą vienas kitam (Everdingen, Fok, Stremersch, 2009). Dinamiškos, sudètingos ir sunkiai prognozuojamos aplinkos veiksnių įtakos šalies ekonomikai tyrinejjimas ir persiliejimo efekto potencialo vertinimas sudaro prielaidas toliau gilintis ị dabartinès globalios aplinkos pokyčių vertinimą vykstančių struktūrinių permainų kontekste. Veiksnių vertinimo metodologinis požiūris

1 Marija Kučinskienè - profesorè, daktarė (socialiniai mokslai). Vilniaus universiteto Ekonomikos fakulteto Verslo katedra

Moksliniai interesai: verslo strategijos, strateginis valdymas, strateginis planavimas

El. paštas: marija.kucinskiene@ef.vu.lt

Tel. +370 52366137

2 Dainius Baliūnas - doktorantas, Vilniaus universiteto Ekonomikos fakulteto Verslo katedra

Moksliniai interesai: verslo organizacijų valdymas, persiliejimo veiksnių analizė organizacijose

El. paštas: dainius.baliunas@kf.vu.lt 
neginčytinai suteikia galimybę prognozuoti tikètinus persiliejimo (angl spillover) ${ }^{3}$ įtakos rezultatus (teigiamus ar neigiamus) ir modeliuoti optimalius sprendimus. Kadangi persiliejimo procesai kiekvienu atveju yra unikalūs, jų poveikio galimybès ir vertinimas turètų leisti modeliuoti tipinius sprendimus paskiriems ekonominės veiklos paslaugų sektoriams: finansų ir draudiminės veiklos, nekilnojamojo turto, mažmeninės prekybos ir kituose paslaugų, kuriuose sukuriama 45,1 proc.i BVP dalies (2015 m), sektoriuose.

Tyrimo tikslas: remiantis teorinių ir praktinių literatūros šaltinių studija, ịvertinti persiliejimo veiksnius ir išskirti jų sklaidos verslo organizacijose problemas.

Taikomi metodai: literatūros aprašomasis, lyginimo, apibendrinimo, interpretavimo, lyginamosios ir sisteminès analizès metodai.

\section{Persiliejimo samprata ir įvairovè}

Taikant mokslo darbuose analiuojamus teorinius ir taikomuosius persiliejimo veiksnių vertinimo metodus, ėmẻ ryškèti būtinybė verslo organizacijose išskirti problemas, susijusias su teoriniu konceptualiu ir holistiniu požiūriu ị inovatyvių sprendimų formavimą ir jų prièmimą, siekiant išaiškinti jų veiksmingumą verslo organizacijoms artimoje ir tolimoje perspektyvoje. Verslo organizacijos, siekdamos konkurencinio pranašumo prieš kitus rinkos dalyvius savo strateginès vadybos gebejjimus turi panaudoti tam, kad būtų sukurta palanki veiklos ir jos rezultatų gerinimo aplinka, nukreipta į būdų bei priemonių paiešką, siekiant patenkinti konkrečių interesų grupių lūkesčius.

Ekonominès veiklos (ar pramonès šakos) ir jų sektoriai yra pavieniai organizmai, susirūpinę savo padètimi globalioje rinkoje, tačiau savo pačių interesų labui ir ypač siekiant masto ekonomijos ar „persiliejimo“ naudos / žalos (galimas šalutinio efekto pasireiškimas), jie turi žinoti, kas vyksta kitose pramonės šakose ir sektoriuose, tai savo ruožtu paverčia juos kitų pramonės šakų ir sektorių veiksmų iniciatoriais ar reaktyviais stabdytojais. Sektoriai turi gebėti ịsitraukti ị globalios ekonomikos integracinius procesus. Sektoriuje, kuris veikia globalioje erdvejje, įmonių konkurencinès pozicijos vienoje šalyje yra priklausomos nuo jų pozicijos kitose šalyse (Kučinskienė, 2010). Verslo sektoriai turi siekti konkurencinio pranašumo prieš kitus rinkos dalyvius. Nežinant ir nesinaudojant šiandieniais išorinių persiliejimo veiksnių poveikio prognozavimo metodais, tai tampa beveik neịmanoma (Iacoviello, Neri, 2008). Iš esmès verslo sektorius, siekdamas apsaugoti savo ekonominę veiklą nuo neigiamo išorinių veiksnių poveikio, tampa įstatymų pasikeitimų iniciatoriais, kartais net privalomai reikalaujant savo valstybių narių valdžios, kad būtų priimti jų veiklai ar jos plètrai svarbūs nauji ịstatymai ar vyriausybės nutarimai.

Persiliejimas - tai poveikis, kylantis iš pagrindinio veiksmo, nenumatytas pagrindinio veiksnio vykdymo charakteristikose (The free Dictionary). Persiliejimas - tai įvykiai, vykstantys viename kontekste, kurių kilimą lèmé kitas negiminingas kontekstas (Business Dictionary). Persiliejimo veiksnio atsiradimą lemia šalutinis poveikis, kylantis iš nenumatyto šaltinio (Weyerstrass, 2006). Persiliejimo veiksnys arba veiksmas, bet koks netiesioginis efektas, veikiantis viešaji sektorių (Hass, 1992), ekonominiai veiksniai, veikiantys vieni kitus tiesiogiai nesusijusiame kontekste kaip aplinkos veikimo ir aplinkos poveikio organizacijai būdai (Vansteenkiste, 2007). Atkreipiant dèmesị ị apibūdinimų ịvairovę, galime pastebèti, kad būtina nuolat tikslingai tobulinti ir plètoti persiliejimo sąvokų visumą, konceptualų teorinių persiliejimo klausimų nagrinėjimą termino kilmès raidos, ypatybių ir persiliejimo veiksnių klasifikavimo požiūriu.

Persiliejimo, kaip termino, populiarumas ir pritaikomumas metams bėgant plečiasi ir ịgyja naują atspalvị, kurio kontekste išryškèja persiliejimo efektas (ang. Spillover effect), orientuojantis ị holistiniu požiūriu paremtą integruojančių ryšiu nustatymą, kuriuos sunku ir sudetinga keisti ar papildyti dinamiškoje veiklos aplinkoje. Siekis ịsitvirtinti sudètingoje ir ịvairialypeje aplinkoje lemia naują požiūrị i aplinkos vertinimą, susijusį su teoriniu konceptualiu ir sisteminiu požiūriu ị aplinkos strateginę vadybą (Kučinskiene, Marčinskas, 2013). Integruojančių ryšių nustatymo problematika, nors ir sudėtinga, verčia tobulinti jų vertinimo

Autoriai sutaria dèl persiliejimo sąvokos (angl. spillover) traktavimo ir vartojimo tyrimuose, tačiau dèl veiksniu kilmés ir jų veiksmingumo potencialo nuomonès išsiskiria ị dvi pagrindines teorijas - neofunkcinę ir institucinę arba klasikinę bei neoklasikinę persiliejimo veiksnių analizès teorijas. 
ịrankius ar analitines technikas. Tai ypač sietina su persiliejimo veiksnių kilmės ir kilmės šaltinių nustatymu. Pažymètina, kad persiliejimo efekto ir persiliejimo veiksnių veiksmingumo kintantis kontekstas įvairiuose moksluose suprantamas ir aiškinamas skirtingai. Viena mokslo šakų, taip pat tirianti persiliejimo efekto problematiką, yra socialiniai mokslai, kur persiliejimo efekto pasireiškimas vienu atveju suprantamas kaip ekonominiai priežastiniai tarpusavyje susiję ịvykiai, kitu atveju - kaip ekonominiai tarpusavyje nesusiję įvykiai, nulemti veiksnių, darančių įtaką inovatyvių sprendimų formavimuisi ir tokių sprendimų prièmimui. Šiuolaikinis persiliejimo veiksnių veiksmingumo apibūdinimas - tai persiliejimo veiksnių, generuojamų rinkoje, poveikis organizacijai ir organizacijos viduje kuriamų inovatyvių sprendimų persiliejimas bei įtaka rinkos redukavimui ir vystymuisi.

Vertinant persiliejimo svarbą - investicijų poveikị verslo organizacijoms, negalima apsiriboti požiūriu „čia ir dabar“", bet naudinga suvokti ši poveikị per ilgą laiką. Todèl moksliniai tyrimai turi būti orientuoti ị inovatyvių sprendimų formavimą ir jų prièmimą, siekiant išaiškinti jų veiksmingumą verslo organizacijoms artimiausioje ir tolimoje perspektyvoje. Persiliejimą veikiančių išorès ir vidaus veiksnių poveikis kuria naudą verslo organizacijoms, inicijuojančioms inovacijas ir, vykdydamos technologinių inovacijų sklaidą, kuria šalutinę naudą kitoms organizacijoms tiek vietineje, tiek užsienio rinkoje.

Inovatyvumo skatinimo ir jo ịgyvendinimui būtinų investicijų pagrindimo, naujosios vadybos priemoniu atrinkimo ir jų taikymo tyrimai tampa ne tik išskirtinès svarbos sritimi verslo organizacijose, bet ir išskirtinai sudėtinga tyrimų sritimi (Kučinskiene, Marčinskas, 2013).

Literatūros šaltiniai konceptualiai nagrinėja persiliejimo veiksnių ekonominę prigimtį, jų skirstymo kriterijus ir veikimą investicinėse kapitalo rinkose bei dinamišką sklaidą, igalintą šiuolaikinių technologiniu priemonių. Persiliejimo veiksnių supratimas siejamas su verslo organizacijų veikla globaliose rinkose, kuri veikiama plataus veiksnių spektro finansinių, technologinių kilmės charakteristikų. Konceptualią analizę reikètų patikslinti keliomis sąvokomis, kurios sukonkretintų persiliejimo veiksnių apibrèžimą ir sąvokų taikymą verslo organizacijų praktinejje veikloje. Dažniausiai pasitaikantis aiškinimas, kad išoriniai persiliejimo veiksniai - tai vyriausybių ar virš nacionalinių (ES) organizacijų poveikis verslo organizacijoms (Haas, 1992). Kita persiliejimo veiksnių grupe sietina su konkrečiuose ekonominės veiklos sektoriuose priimamais inovatyviais sprendimais ir jų sukuriamu persiliejimu arba persiliejimo veiksnių daromu teigiamu ar neigiamu poveikiu. Tokie persiliejimo veiksniai refleksyviai veikia rinkos dalyvių elgseną ir ekonominius sprendimus. Vartotojai, igyjantys produktus, kurie sukurti persiliejimo veiksniams veikiant inovacinius produktus, laimi ne tik kainos požiūriu, bet ir igauna papildomų galių dalyvauti rinkos plètros procese. Teigiant, kad inovatyvių produktų kūrimas yra pozityvus veiksnys, nulemtas teigiamo potencialo persiliejimo veiksnių, tuo tarpu nesèkmes galima būtų priskirti neigiamą poveikị darantiems veiksniams. Šalutinis persiliejimo poveikis (dažniausiai apibrěžiami išorès veiksniai) būdingas ekonominès veiklos poveikị turintiems jègos ūkio subjektams (visuomenei, vyriausybei, verslo organizacijoms ir kt.), kuris tiesiogiai nesusijęs su organizaciju veikla. Naujovių ir technologijų plètrą ir sklaidą generuoja žinių srautai, perduodami taikant technologijas arba socialinèje-kultūrinèje aplinkoje, atskleidžiantys verslo organizacijų, visuomenès, institucijų, vyriausybès ekonominès veiklos kryptis. Naujovès, kurias vertina vartotojai, susijusios ne tik su kainos ar produkto savybėmis, bet ir su aplinka, ị kurią vartotojas patenka turedamas naują produktą. Aplinkos poveikis ir sukuriami persiliejimo veiksniai gali skatinti vartotojus domètis verslo organizacijos kuriamais inovatyviais sprendimais ir atvirkščiai - atgrasyti nuo norimo pasirinkimo. Socialinių veiksnių poveikio negatyvumą patiria verslo organizacijos, kurios koncentruojasi ị technologijų kūrimą visiškai pamiršdamos vartotoją supančius du pagrindinius socialinès aplinkos žiedus. Inovatyvių produktų kūrimas ir diegimas nuolat keičiantis vidiniams bei išoriniams rinkos persiliejimo veiksniams, šio proceso racionalus valdymas neabejotinai lemia tokių produktų sèkmę dinamiškoje rinkoje ir turi poveikį rinkodaros sprendimams bei su tuo susijusioms sąnaudoms. Svarbu pastebėti, kad inovatyvaus produkto kūrimo ir diegimo palaikymo procesas, koreliuojantis su vidiniais ir išoriniais rinkos persiliejimo veiksniais, turètų prisidèti prie to, kad viso inovatyvaus produkto gyvavimo ciklo sėkmingumas sukurtų organizacijai vis didesnę pridedamąją vertę. 


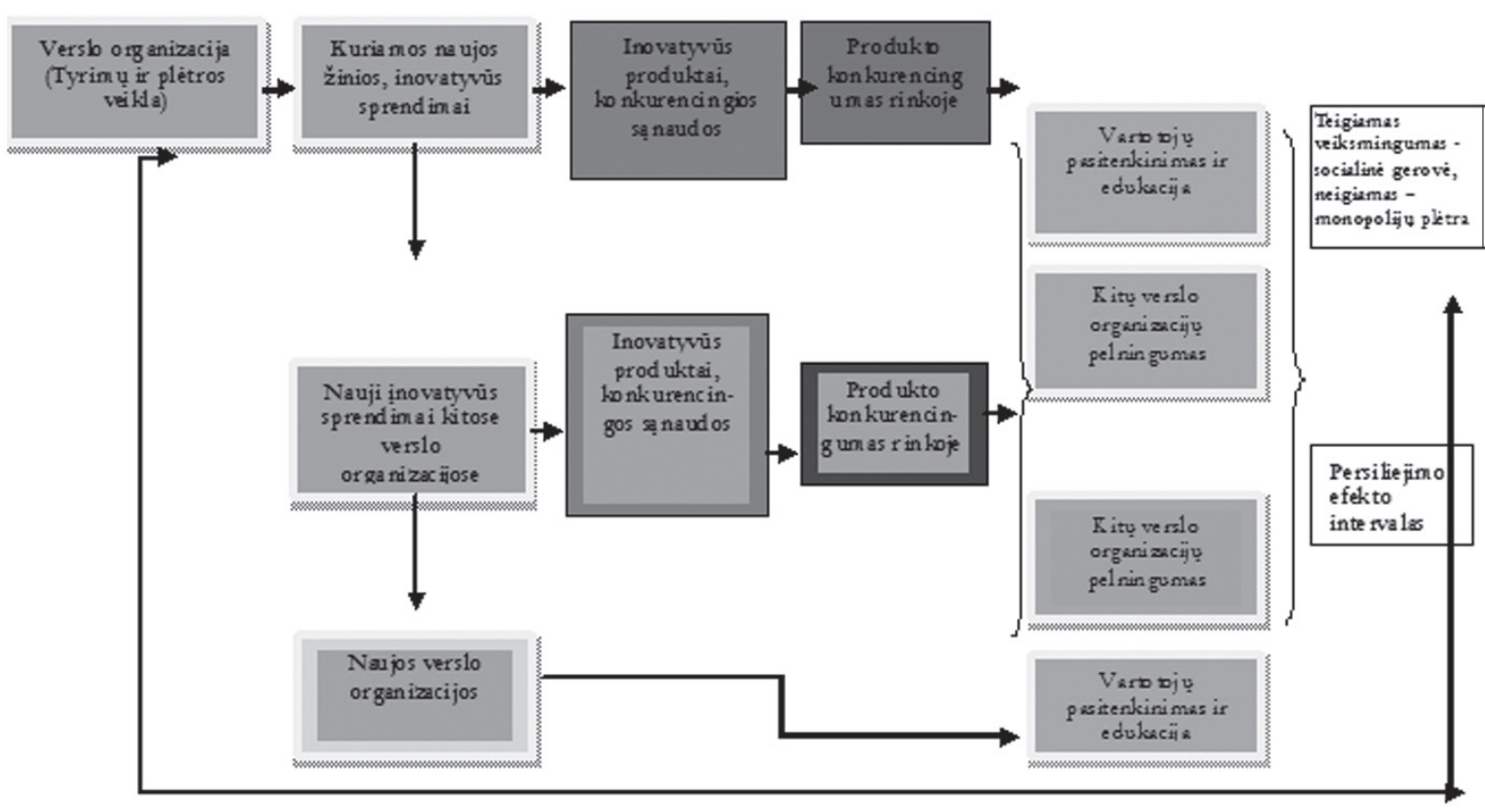

1 pav. Persiliejimo veiksniai, jų poveikis verslo organizacijoms

Verslo organizacijų plètra globalioje holistinejje rinkoje siejama su kapitalo, darbo išteklių ir turimos patirties veiksnių sklaida skirtingais pjūviais - horizontaliai ir vertikaliai. Vienose rinkose sukaupta patirtis perkeliama ị kitas, taip veikiant skirtingų rinkų infrastruktūrą, vartotojų ịpročius ir darant poveiki naujo produkto vartojimui. Toks žinių ir sukauptos patirties perkèlimas (ar sklaida), transformavimas tarp rinkų (elektroninę erdvę - internetą traktuojant kaip vieną globalią elektroninių duomenų aplinką - GEDA) nelieka be atsako. Vienos rinkos reaguoja gana skausmingai, nes praranda daug darbo vietų dèl gaminamų, geriau tiktų, padirbinėjamų žymių prekių ženklų produktų neturint tam intelektinės nuosavybės teisių (INT), kitos gi (rinkos), suprasdamos žinių, technologijų ir naujovių sukeliamas persiliejimo bangas, puikiai tuo naudojasi vystydamos konceptualiai naujas žinių visuomenes, kurių veiklos sektorių efektyvumas grindžiamas konkurencija ir verslo organizacijų heterogeniškumu.

Verslo organizacijos, nepaisant jų dydžio, vis dažniau tampa ne tik vietinès rinkos dalimi, bet ir turi galimybių naudotis naujausia pasauline technologine, žinių perdavimo bei vadybos patirtimi. Vertindamos integracijos ị pasaulinę rinką svarbą, jos aktyviai vykdo plètrą GEDA erdvejje. Didžiosios globalios pasaulinès verslo organizacijos, siekdamos konkurencinio pranašumo ir efektyvios plètros, priverstos kaip išteklius naudoti skirtingose rinkose esančias organizacijas, taip persiliejimo veiksnių dèka jos skleidžia savo patirti ir inovatyvius produktų, žinių, technologijų sprendimus.

Verslo efektyvumas grindžiamas sąnaudų, tiesiogiai nesusijusių su kuriamu produktu, ,iškèlimu“ iš organizacijos, kartu iškeliant ir svarbias organizacijai funkcijas, tokias kaip finansinę apskaitą ir auditą, personalo atranką bei mokymus, technologinę IT priežiūrą, rinkodarą, skirstymą ir kitas funkcijas. Viena svarbiausių verslo organizacijų užduočių tampa iškeltų išorèn funkcijų valdymas bei kontrolè, bet kuriamas abipusiai naudingas bendradarbiavimo tinklas. Taip išoreje esančios nepriklausomos organizacijos per IT ar kitus ịmanomus ryšius tampa vientisu rinkos organizmu, ekonominès veiklos sektoriaus vertikalioje erdveje dalimi, pačios veikiamos persiliejimo veiksnių kuriant naujus produktus bei inovatyvius sprendimus didžiosioms globalioms organizacijoms ir lygiagrečiai rinkai. Tarp globalių ir vietos verslo organizacijų susidaro trys tyrimo sritys, tiesiogiai veikiančios persiliejimo veiksnių kilmę ir plètrą: ryšių tarp organizacijų formavimo prielaidos, technologinè plètra ir tarpusavio jungčių būdai. Konceptuali verslo organizacijų analizè nurodo penkis pagrindinius veiksnius: tiekimas grandinèje, kur produktas yra kito proceso pradžios šaltinis (žaliava), persiliejimo veiksniai, veikiantys partnerius konkurentus ir šalia veikiančias kitas verslo organizacijas. 


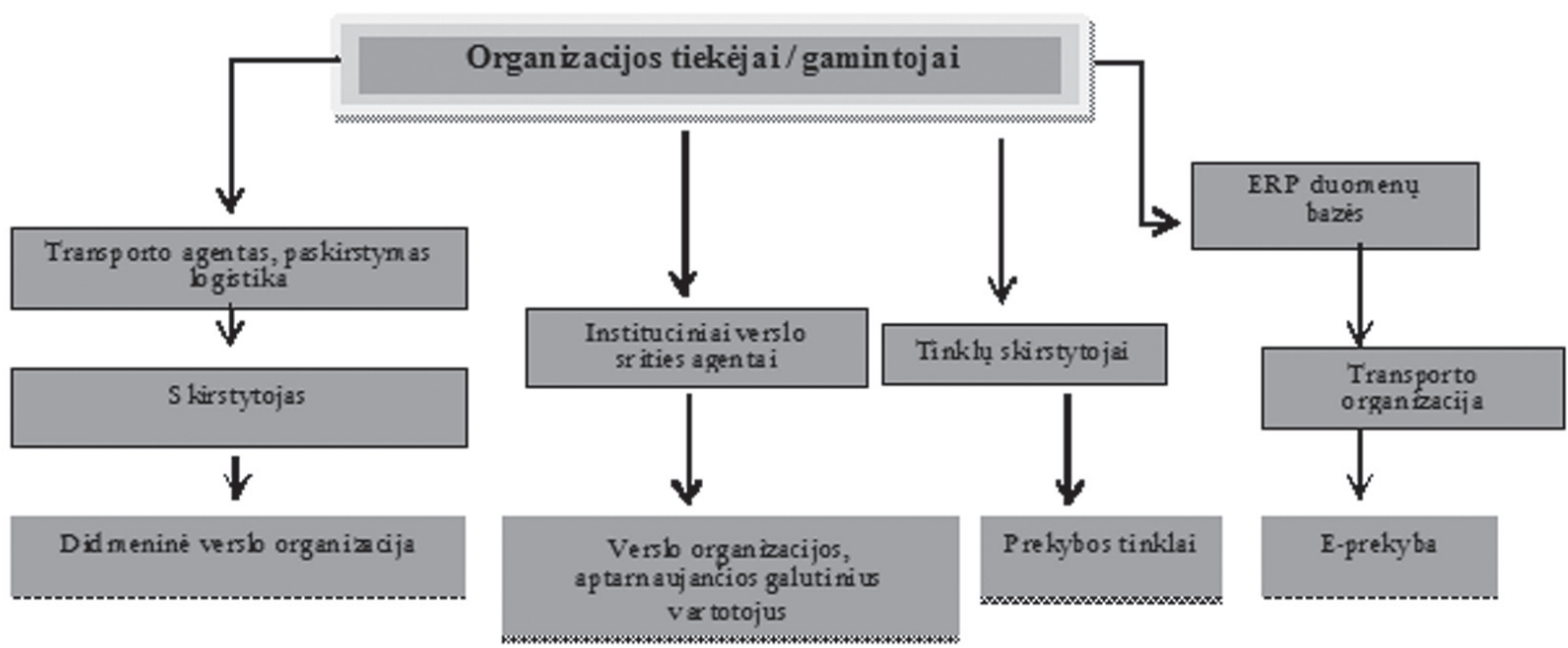

2 pav. Kompleksinè ryšių grandinè tarp tiekèjų ir gamintojų verslo organizacijose

Šiuolaikinių verslo organizacijų efektyvumas priklausomas nuo ryšių su tiekejjais, tiesiogiai nuo pasirinktų tiekejjų galimybių, jų produktyvumo ir produkcijos pateikimo laiku. Organizacijos, siekdamos būti lanksčios, sutelkia aplink save efektyvius tiekimo tinklus, ị kuriuos įtraukia tiek didelius, tiek vidutinio dydžio ir smulkius verslus. Numatant kuriamų produktų specifiką, numatomas preliminarus tiekejjų sąrašas, kituose etapuose ,piltuvėlio“ principu išskiriant ir separuojant patikimas tiekimo verslo organizacijas bei su jomis sudarant tiekimo sutartis.

Taigi tiekejjų rinkoje generuojamas persiliejimo veiksnys, veikiantis organizacijų vidines struktūras, gali keistis taip, kaip reikalauja užsakovas, dažniausiai tai pelninga ir patrauklu, tačiau yra nemažai pavyzdžių, kai tiesiog išnaudojamas mažesnis verslas dèl jo masto (mažesnès apimties) ir negebéjimo kurti globalias konkuravimo strategijas. Toks persiliejimo veiksnio atsiradimas gali būti sietinas tiek su teigiamu, tiek ir su neigiamu veiksmingumu rinkai, juk nukenčia ne didysis gamintojas, o rinka: pažeidžiamas rinkos heterogeniškumas ir galimybe generuoti sąnaudas bei kurti inovacijas. Dažniausias teigiamas veiksnys rinkos tiekejjams yra laiku atliekami mokejjimai už tiekimus ir galimybė naudotis sukurtomis technologijomis. Didžiosioms verslo organizacijoms patrauklu ne tik dèl pasirinkimo teisès, bet ir svarbu amortizuoti rinkose vykstančius pokyčius, kai kinta paklausa ir keičiasi vartotojų poreikiai. Inovatyvius produktus kuriančios organizacijos yra priklausomos nuo savo tiekèjų ir produkcijos realizavimo kanalų, todėl sudaromos sąlygos tiekẻjams tobulintis savo organizacijų strategijas, vadybines struktūras ir technologijų plètrą, atsižvelgiant ị sukurtą inovaciją. Sukūrusi produktą organizacija privalo priimti strateginius sprendimus, kurios produkto gamybos ir tiekimo rinkai proceso dalys bus kontroliuojamos pačios organizacijos, o kurios - perduotos rinkai. Taip sukurta inovacija generuoja persiliejimo veiksnius ị rinką ir organizacijos viduje. Atlikta mažmeninės prekybos avalyne ir IT organizacijų tyrimo duomenų analizė nurodo, kad kiekvienu paskiru atveju toks požiūris suteikia galimybę suprasti vykdomų veiklų tarpusavio sąsajas tiek organizacijos viduje, tiek išorèje, nurodant analizuojamų procesų priklausomybes bei jų (analizuojamų procesų) tarpusavio sąsajų ryšius ir potencialias vertes.

Atlikus Lietuvos avalynės prekybos sektoriuje (apklaustos 54 organizacijos) veikiančių tiekimo įmonių analizę ir IT technologijų tiekimo sektoriuje (apklaustos 32 organizacijos) veikiančių i̇monių, teikiančių paslaugas analizę, nustatyta, kad didžiausias persiliejimo veiksnių potencialas generuojamas organizacijų pagrindinès veiklos procesuose. Šių veiksnių analizė atskleidžia jų tolesnę plètrą ir persiliejimą ị kitas verslo organizacijas, nes kintant bent vieno grandinès dalyvio struktūrai, kinta ir kitų sąveikaujančių dalyvių tarpusavio bendradarbiavimo technologijos bei mechanizmai (procesai). 
1 lentelè. Persiliejimo veiksnių veiksmingumas kitų verslo organizacijų veiklos procesams (procentais)

\begin{tabular}{|c|c|c|}
\hline Organizacijų veiklos procesai & $\begin{array}{l}\text { Prekybos } \\
\text { organizacijose }\end{array}$ & $\begin{array}{l}\text { IT technologijuc } \\
\text { organizacijose }\end{array}$ \\
\hline Bendradarbiavimas nustatant kokybinius parametrus & 100 & 84 \\
\hline Apsikeitimas informacija vadybininkų lygmeniu & 73 & 68 \\
\hline Patarimai dèl organizacinès struktūros plètros & 100 & 54 \\
\hline Pagalba organizuojant darbuotojų mokymus & 100 & 50 \\
\hline Reikiamos įrangos ir produktų nuoma (skolinimas) & 50 & 31 \\
\hline Skubi pagalba & 75 & 26 \\
\hline $\begin{array}{l}\text { Pagalba organizuojant aptarnavimą po pardavimo ir remonto-priežiūros } \\
\text { darbus }\end{array}$ & 50 & 15 \\
\hline Pagalba rengiant ilgalaikius investicinius projektus & 25 & 15 \\
\hline Bendradarbiavimas atliekant tyrimus & 25 & 7 \\
\hline Finansavimo šaltinių paieška & 25 & 10 \\
\hline
\end{tabular}

Verslo organizacijos, aptarnaudamos tiek išorinius, tiek vidinius klientus, ir siekdamos konkurencinio pranašumo rinkoje, kuria naujus - inovatyvius aptarnavimo sprendimus. Tokių sprendimų kūrimas ir registravimas, patentavimas bei standartizavimas sudaro persiliejimo ị kitas verslo organizacijas veiksnių atsiradimo rinkoje prielaidas. Idiegtas naujas standartas, sukurtas inovatyvus produktas ịpareigoja tiekejjus, skirstytojus, remonto organizacijas keisti vykdomą veiklą, atsižvelgiant ị rinkos sąlygas. Kiekvienas organizacijos procesas, skirtingai veikiamas rinkoje verslo organizacijų generuojamų vidinių ir išorinių persiliejimo veiksnių, pavyzdžiui, nustatant kokybinius produkto kūrimo bei aptarnavimo rodiklius, yra esminis ir vienodai svarbus tiek tiekiančiai organizacijai, tiek aptarnaujančiai galutinị vartotoją bendradarbiavimo tyrimų srityje procesas. Tuo tarpu bendradarbiavimas plètros ir tyrimų bei inovatyvių produktų kūrimo srityse yra gana ribotas, ji reikia kruopščiau ištirti turbūt dèl spragų intelektinès nuosavybès registravimo ir apsaugos srityse (1 lentelè).

Apibendrintai galima teigti, kad organizacijų veiklos procesams didžiausią ịtaką daro sritys, kurios yra gyvybiškai svarbios ne tik tiekejui ir galutiniam pardavejui, bet ir to produkto vartotojui ir yra tiesiogiai susijusios su organizacijų vertès kūrimu bei jos didinimu.

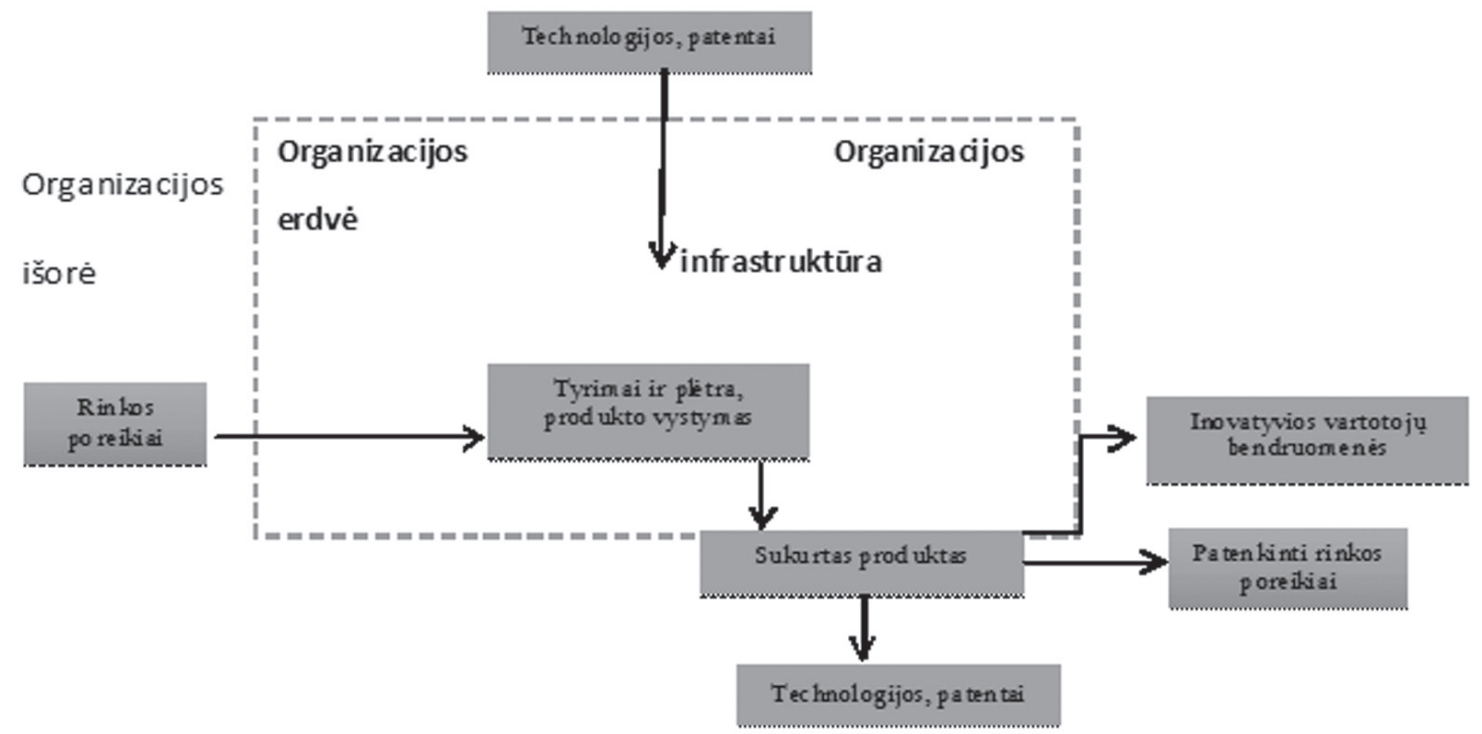

3 pav. Verslo organizacijų produkto kūrimo ir bendradarbiavimo su tiekëjais bei klientais procesų persiliejimo veiksnių kilmès šaltiniai 
Tiekejų tinklo vystymas ir modernių valdymo metodų taikymas suteikia konkurencinį pranašumą verslo organizacijoms, kurios produkto kūrimo etapus (nebūtinai pačius svarbiausius), siekdamos maksimalaus efektyvumo, perkelia ị tiekimo grandines. Išlieka tik operatyvinio valdymo klausimas, ypač kai taikoma ar siekiama taikyti EDI (elektroninių duomenų mainų sistemas), kurios užtikrina savalaikị reikiamų komponentų tiekimą. Paskiri tiekimo grandinès elementai turi veikti kaip visuma ir be sutrikimų tiekti reikiamą žaliavą, medžiagą ir pan. produktui kurti, taip dalyvauti tiekimo tinkle ir skatinti persiliejimo veiksnių plètrą.

Skirtingos organizacijos su vartotojais kuria skirtingus ryšius, tačiau pagrindinis ryšių kūrybos metodas yra rinkodaros sprendimai ir jų igyvendinimo būdai. Organizacijos, kuriančios globalioje erdvèje veikiančius produktus, dažniausiai skirstymą patiki išorinėms paskirstymo organizacijoms, tuo tarpu pačios siekia ne tik ịtvirtinti, bet ir didinti prekès ženklo vertę. Taip greitai pasiekiamos skirtingos rinkos, nenaudojant didelių finansinių investicijų, koncentruojant savo veiklą į produktų kūrimą ir rinkodarą. Sukuriamas aiškus homogeniškas produkto pasiūlos rinkai sprendimas. Žinomų prekių ženklų atstovavimas skirstytojui sukuria papildomą naudą (pajamos, licencijos, franšizè) bei veikia aplink esančias verslo organizacijas: skatina inovatyvius sprendimus ir konkurenciją. Kitas ne mažiau svarbus ryšių su vartotojais tipas - techninis konsultavimas ir mokymai, siekiant užtikrinti rinkoje platinamų produktų maksimalią naudą. Tai sudètinè rinkodaros komplekso dalis, generuojama organizacijos gamintojos, tačiau tai igyvendinama kartu su skirstytoju, siekiant, kad vartotojas, ịsigijęs produktą, naudojamą kaip žaliavą, medžiagą ar komplektavimo gaminius, savo versle gautų maksimalią išeigą - galutinio rezultato naudą organizacijos vidaus ir jos išorès interesų grupèms.

Technologinių žinių ir inovatyvių sprendimų kilmès šaltinis tapatinamas su rinkos konkurencingumu. Globalioje erdvejje veikiančių verslo organizacijų veikla naujose rinkose generuoja persiliejimo veiksnius konkurencinèje organizacijų aplinkoje, kur labiau atsilikusios organizacijos siekia tobulinti savo procesus, pritraukdamos išorini kapitalą (horizontalus persiliejimo veiksnys - į finansų sektorių), žmogiškuosius išteklius (vertikalus persiliejimo veiksnys), žinių perdavimą ir technologijas (tiek vertikalus, tiek horizontalus). Kurdamos naujus inovatyvius sprendimus organizacijos ne tik keičia vartotojų ịpročius, bet kartu ir aplinką, kurioje veikla vykdoma. Kaip minèta skyriaus preambulèje, tokia konkurencija generuoja ne tik teigiamą persiliejimo veiksnį, bet ir neigiamą, nes rinka tampa oligopolinè ir trukdo endogeninių (būdingų tai rinkai ar kylančių iš tos pačios rinkos) technologijų plètrai.

Išvados

Sukurti globalu produktą neįmanoma be technologinių partnerių, kurie turi reikiamas kompetencijas, technologijas ir išteklius. Rinkose verslo organizacijų inicijuojamas strateginių aljansų steigimas, licencijų prekybos ir franšizès sutartys, išnaudojant abipusiai naudingą patirtį ir apsisaugant nuo intelektinès nuosavybės teisių pažeidimų bei technologijų nutekẻjimo. Savanoriškai atsirandantys aljansai naudingi abipusiai, organizacija davėja, technologijos savininkè, užsitikrina IN apsaugą, tuo tarpu gavėjas - prieigą prie inovatyvių produktų ir galimybę tobulèti.

Demonstracinio poveikio vartotojui persiliejimo veiksniai kyla verslo organizacijoms pristatant naujus produktus, inovatyvius technologinius sprendimus, taikant naujosios vadybos metodus. Organizacijai pristatant rinkai naujovę generuojamas persiliejimo poveikis visoje rinkoje, tai dažniausia vyksta spontaniškai, tačiau nereti atvejai, kai rinka laukia ir sistemingai tiria vieną ar kitą verslo organizaciją bei jos naujovių kūrimo mechanizmą.

Žmogiškujų išteklių kuriami persiliejimo veiksniai sietini su inovatyvių organizacijų veiklos procesais, užduočių atlikimo laiku ir efektyviu technologijų taikymu. Tokių verslo organizacijų darbuotojai gali perteikti savo ịgūdžius rinkai perẻję dirbti ị kitą organizaciją, sukūrę savo įmonę ar tiesiog dalyvaudami partnerių mokymuose.

Verslo organizacijos rinkoje generuoja pagrindines persiliejimo veiksnių grupes, kurių svarbą ir veiksmingumą galima atskleisti tiriant vertikalius ir horizontalius ryšius bei priklausomybes, kartu ịvertinant tụ 
veiksnių gebëjimą persilieti ị kitus sektorius ir taip verslo organizacijas siekti vis didesnès pridedamosios vertès.

\title{
Literatūra
}

Business Dictionary. (2016). WebFinance Inc. Prieiga internete: http://www.businessdictionary.com/definition/spillover-effect.html [žiūrèta 2016.08.10].

Bloom, N., Schankerman, M., Reenen, J. (2013). Identyfying technology spillovers and product market rivalry. Econometrica. Journal of the Econometric Society, Vol. 81, Issue 4, p. 1347-1393.

Blomstrom, M., Kokko, A. (2015). Multinational Corporations and Spillover. Journal Economic Surveys ISI Journal Citation Reports. ISSN: 1467-6419.

Bronwyn, H. (1999). Innovation and Market Value. National Bureau of Economic Research. Working Paper, No. 6984.

Everdingen, Y., Fok, D., Stremersch, S. (2009). Modelling Global Spillover of New Product Takeoff. Journal of Marketing Research, Vol. XLVI, p. 637-652.

Gelos, R. G., Sahay, R. (2001). Financial market spillovers in transition economies. Economics of Transition, Vol. 9 , p. 53-86.

Peter M. Haas. (1992). Epistemic Communities and International Policy Coordination International Organization. Knowledge, Power, and International Policy Coordination, Vol. 46, No. 1, p. 1-35.

Iacoviello, M., Neri, S. (2008). Housing market spillovers: evidence from an estimated DSGE model. Banca d'Italia Eurosystema. Temi di discussion, No. 259.

Kučinskienė, M. (2010). Paslaugu verslas integruotoje rinkoje: Permainos ir tendencijos. Vilnius.

Kučinskienė, M., Marčinskas, A. (2013). Verslo plètros galimybės vyriausybės programų kontekste. Regional formation and development studies, Nr. 2 (10), p. 98.

Sbragia, A. M. (2001). Environmental Policy: Economic Constraints and External Pressures. Ch. 11 in Wallace and Wallace, p. 293-316.

Jounes, E., Verdun, E. (2005). The Political Economy of European Integration. Routledge New York, p. 3-26.

Moravcsik, A. (1993). Preferences and Power in the European Community: A Liberal Intergovernmentalist Approach. Journal of Common Market Studies, Vol. 31, No. 4, p. 473-524.

The Free Dictionary: Dictionary, Encyclopedia and Thesaurus. (2003-2016). Farlex, Inc. Prieiga internete: http://encyclopedia.thefreedictionary.com/spillovers [žiūrèta 2016.08.10].

Vansteenkiste, M. (2007). Regional housing market spillovers in the US lessons from regional divergences in a common monetary policy setting. European Central Bank, European Central Bank, p. 708.

Weyerstrass, K., Jaenicke, J., Neck, R., Haber, G., Aarle, B., Schoors, K., Gobbin, N., Claeys, P., (2006). Economic spillover and policy coordination in the Euro Area. European Commission, No. 246.

Zoltán, Á., Sanders, J. (2008). Intellectual property rights and the knowledge spillover theory of entrepreneurship. Planck Institute of Economics research papers, No. 8,069.

\section{DISPERSION OF THE SPILLOVER POTENCIAL IN BUSINESS ORGANIZATIONS}

\author{
MARIJA KuČINSKIENĖ, DAINIUS BaliūNAS \\ Vilnius University (Lithuania)
}

\section{Summary}

This paper examines and provides overview of relationships in global rivallity between companies and industries and impact of various actors with potential spillover effect horizontally in different industries and vertical in the same industry. Several interesting research questions remain to be answered, in particular analysis actual horizontal spillovers coming from a different source influencing not only companies from the same sector, but also, in large scale, industries and sometimes even state economic policy. 
Innovative leadership on business development important at all levels of the organization and in each process. The ability for immediate respond to market changes and understanding that innovation is the main objective of business to remain competitive during the external market and internal organization changes in the application of leadership, adaptability and cost-effective methods of exploitation. In particular, companies need to understand how to manage an innovative internal organization influenced by both internal and external factors. The ability to create and manage internal traditions and creative environment provides the basis for the successful development of innovative business cases for the implementation. Circumstances change in the management of organizations operating in global markets, successfully implement leadership initiatives by harmonizing relations based leadership style strengths and eliminating weaknesses.

Secondly, IT technology and social e-environment is only tools and techniques to understand the possible changes and their spillovers and affect to the business potential. The main task is to keep the backbone of the organization applying innovative management and strategic development methods, while maintaining the traditional market activities and channels for the new environments.

KEY WORDS: business organization, spillover, factors, innovations.

JEL CODES: O30, M 10

Priimta: 2016.08 .28

Recenzuota: 2016.09.25

Pasirašyta spaudai: 2016.10.01 